\title{
Kosovo and the Evolution of State Sovereignty
}

\author{
Gary Schaub, Jr.
}

\begin{abstract}
The author argues that NATO's intervention in response to the $Y$ ugoslav government's repression in Kosovo may accelerate the intermational community's acceptance of the liberal-democratic notion of popular sovereignty over the Westphalian notion of state sovereignty. The tension between these rival conceptions, planted in the UN Charter itself, gestated throughout the Cold War. Unlike the incremental steps toward accepting notions of popular sovereignty taken by the international community since the Cold War's end, NATO's Kosooar intervention has brought this rivalry into bold relief. Will the wider international community accept the West's conception of popular sovereignty? Although initial indications are good, wide acceptance is contingent upon NATO's success in Kosovo-and eoen then, only time will tell.
\end{abstract}

\section{Résumé}

L'auteur présente uneargumentation selon laquellel'intervention del'OTANen réponsed la répression du gouvernement yougoslave au Kosovo pourrait accélérer l'acceptation par la communauté internationale de la notion libérale-démocrate de souveraineté populaire sur la notion westphalienne de souverainetédes états. La tension entre ces deux conceptions rioales, ressentie jusque dans le libellédela Charte de l'ONU, a mûri pendant la Guerre Froide. Et, contrairement aux phases historiques progressives ayant mené, depuis la fin de la Guerre froide, la communaute internationaled une acceptation de la notion de souverainetépopulaire, l'intervention de l'OTAN au Kosovo a ré-ouvert cette rivalitéd vif. La

Gary Schaub, Jr. is a Ph.D. candidate in the Graduate School of Public and International Affairs at the Unioersity of Pittsburgh. His research centres on coercioe interstate relations and European security issues. communauté internationale élargie pourra-t-elle en venir d accepter la conception occidentale de souveraineté populaire? Quoique les indications initiales soient bonnes, une acceptation profonde et solide dépend du succès de l'OTANau Kosovo. Et même dans cette éventualité seul le temps permettra de dire ce qu'il en sera.

NATOaction to right the wrongs visited upon the ethnically Albanian citizens of the Yugoslav province of Kosovo is remarkable in a number of respects. Not only is the current air war virgin territory for the formerly - and formallydefensive 19-member alliance, but it signals what is perhaps the greatest step in the evolution of the concept of sovereignty since its inception in the Peace of Westphalia in 1648.

Much has been made of the NATO countries' disregard for the sovereignty of Yugoslavia by the critics of the Alliance's intervention. On March 26, the Russian ambassador to the United Nations condemned NATO's actions on the grounds that:

The aggressive military action unleashed by NATO against a sovereign State [is] a real threat to international peace and security, and grossly violate[s] the key provisions of the United Nations Charter ... The use of force not only destabilize[s] the situation in the Balkans and the region as a whole, but undermine[s] today's system of modern-day international relations. ${ }^{1}$

The Chinese ambassador declared that:

China strongly oppose[s] the use of or threat of use of force in international affairs, and interference in the internal affairs of other States under whatever pretext or in whatever form. ${ }^{2}$

Yugoslavia's ambassador railed against the NATO actions, saying that they ha[ve] turned a sovereign and peaceful country and its proud people into a killing field and a testing ground for its most sophisticated weaponry, trampling upon international relations and defying the authority of the Security Council. ${ }^{3}$

Meanwhile, his home government blandly commented that "The Federal Government points out that no one has the right to force Serbia and the Federal Republic of Yugoslavia to sign ... a document" that gives Kosovo "the status of a third federal unit or the status of an independent State." 4

That NATO's members do not seem terribly bothered by this gross infraction begs the question: is sovereignty a merenicety of international law that can bedisregarded when other values are at stake?

Of course, sovereignty is much more than that. The Russians and Yugoslavs have a point: sovereignty is the basic principle of international politics. It defines what entities can play the game of nations and establishes its basic rules. In essence, sovereignty constitutes a deal between the rulers of political entities-states-whereby each recognizes the ultimate authority of the other in their respective territorial domains. This entails a concomitant pledge to not interfere in one another's "internal affairs." Sovereignty has been a great boon for world order. It has reduced the amount of interstate conflict by removing internal matters as legitimate reasons for war. Indeed, sovereignty was first enshrined in the Peace of Westphalia because disputes over what entities had legitimate and authoritativejurisdiction over issues such as the rights of religious minorities had driven Europe into an almost constant state of war for over a century. ${ }^{5}$

From the standpoint of international law, sovereignty is absolute and inviolable. Article 2(4) of the United Nations Charter, the primary source of modern 
international law, states that "Allmembers shall refrain in their international relations from the threat or use of force against the territorial integrity or political independence of any state." Article 2 (7) further states that:

Nothing contained in the present Charter shall authorize the United Nations to intervene in matters which are essentially within the domestic jurisdiction of any state.

In reality, however, states have interfered in each other's internal affairs many times. One need only recall the Soviet Union's overt armed interventions in East Germany in 1953, Hungary in 1956, Czechoslovakia in 1968, and Afghanistan in 1979, or the United States' interventions in Guatemala in 1954, Cuba in 1961, the Dominican Republic in 1965, Grenada in 1983, or Panama in 1989, or even North Vietnam's 1979 intervention into Cambodia and Iraq's 1990 invasion of Kuwait, to realize that violations of state sovereignty are not uncommon. The question is whetherNATO'sintervention, unlike these, is a legitimate violation of Yugoslavia's sovereignty.

At the heart of this question lies the issue of just who is sovereign. Today, international law recognizes governments as sovereign, just as monarchs were viewed as the repositories of sovereignty after Westphalia. Liberal-democratic states, however, have dispensed with this notion within their own borders-where "the people" are considered sovereign and the regime governs on their behalf-and are pressing for this norm to be adopted internationally. Over Kosovo they are pressing this view quite hard.

The seeds for this challenge to state sovereignty were planted by thewestern powers 55 years ago in the UN Charter. Articles 55 and 56 state that "all Members pledge themselves to takejoint and separate action" to promote "universal respect for, and observance of, human rights and fundamental freedoms for all." Other multilateral treaties and agreements, such as the Universal Declaration of Human Rights of 1948 and the HelsinkiFinal Act of 1975, have reinforced the argument that "the people" have rights that should be respected by their governments, just as states should respect each other's sovereignty.

Although these ideas merely gestated throughout the Cold War, ever-growing segments of the international community have begun to consider these notions as part and parcel of their mutual recognition of each other's sovereignty. For example, in 1991 the states of the European Community insisted that the republics desiring to break away from Yugoslavia commit to respecting their citizens' individual and minority rights and adopt democratic forms of governmentbefore they would be recognized. ${ }^{6}$ In 1988 and 1991, the UN General Assembly passed resolutions that recognized the rights of civilians to receive humanitarian aid-even over the objections of their governments - after natural disasters and similar emergencies. These resolutions also established the expectation that aid workers would be provided access to those in need and allowed to carry out their duties in "tranquility."

NATO's actions in Kosovo, however, present a qualitatively different challenge to the notion of governmental sovereignty. Kosovo has not petitioned for recognition as a sovereign state. Nor is NATO providing humanitarian aid within Yugoslavia. Where it is doing so-in Albania, Macedonia, and Montenegro-ithas the full cooperation and support of the authorities. So these precedents do not apply. Rather, NATO's stated goal is to alter Yugoslavia's internal political arrangements. In particular, NATO desires to decree where Yugoslavia's police and security forces can be stationed within Yugoslav territory, the degree of authority the Yugoslav federal government will have over its Kosovo province, and insert an armed "international security force" that will act as the ultimate authority within Kosovo. ${ }^{8}$ These are clear violations of Yugoslavia's sovereignty.

Itmight appear that the establishment of "safe havens" for the Kurdish minority in Iraq provides a precedent for this action. In 1991 the UN Security Council approved Resolution 688 , which condemned "the repression of the Iraqi civilian population ... including most recently in Kurdish populated areas," and called on the Iráqi government "to allow immediate access by international humanitarian organizations." It also declared that such repression was "threatening international peace and security in the region"-language that justified the use of force by other states in order toend such a threat. ButOperation Provide Comfort was an anomaly, coming on the heels of Iraq's defeat in a UN military action that had authorized "all necessary means" "to restore peace and security to the area." Most importantly, the states enforcing the safe havensthe United States, Britain, France, and Turkey: NATO members all-repeatedly asserted that they were establishing a humanitarian zone of tranquillity, not a political zone for Kurdish autonomy or self-determination. ${ }^{9}$ Hence, they refrained from challenging the sovereignty of Saddam Hussein's regime despite their desire to see it toppled.

But NATO has picked up this particular gauntlet over Kosovo. NATO Secretary General Javier Solana has stated, "Our quarrel is not with [Yugoslavia's] people but with the government, which has abused its power and has waged war against its own citizens in Kosovo." ${ }^{10}$ Although they still adhere to the "Rambouillet formula" of Kosovar autonomy within Yugoslavia, stopping this abuse and assuring the return of the Kosovar refugees in an environment of peace, stability, and safety cannot occur if Serbian police, military forces, and border guards retain their status as agents of the sovereign authority that will govern Kosovo. Hence, the NATOallies have begun discussing the modalities of establishing an international protectorate over Kosovo, perhaps under the auspices of the European Union or the UN. They recognize the reality that the conflictcan only be settled if Yugoslav sovereignty over Kosovo is revoked in the name of human rights.

Provided that this outcome obtains, what will it mean for the future of sovereignty? Will the sovereignty of the people trump the sovereignty of governments in the future? Will gross viola- 
13.

tions of human rights by other regimes provide legitimate grounds for outside intervention? Ultimately, these questions will turn on the degree of acceptance that NATO's actions gamer in the wider international community. Thus far, indications are positive. UN Secretary General Kofi Annan has reaffirmed his view, enunciated in an address last June, that:

The [UN] Charter protects the sovereignty of peoples. It was never meant as a licence for governments to trample on human rights and human dignity. Sovereignty implies responsibility, not just power. ${ }^{11}$

Of 25 participants in NATO's Partnership for Peace program, only Russia failed to voice its support for NATO's goals and actions at the Washington NATO summit. ${ }^{12}$ In the UN Security Council, 12 of 15 states opposed Russia's draft resolution condemning NATO's actions. $1^{3}$ And, despite its opposition, even segments of Russia' s elite are sympathetic to the basic principle underlying NATO's position. In 1992, then-Foreign Minister Andrei Kozyrev wrote:

Wherever threats to democracy and human rights occur, let alone violations thereof, the international community can and must contribute to their removal ... Such measures are regarded today not as interference in internal affairs but as assistance and cooperation in ensuring everywhere a 'most favored regime' for the life of the peoples-one consistent with each state's human rights commitments under the UN Charter, international covenants, and other relevant instruments. ${ }^{14}$

Tony Blair or Bill Clinton could not have said it better.

Thus it seems that the seeds planted by western statesmen two generations ago, and patiently nurtured since, have taken root. What remains to be seen is if the fruit borne is sweet or rotten. If the "Peace of Pristina" sets a precedent of the international community conditioningthe continued recognition of a state's sovereignty on its humane treatment of its citizenry, perhaps it will join the Peace of Westphalia as a watershed for interstate politics .•

\section{Notes}

1. "NA TO Action Against Serbian Military Targets Prompts Divergent Views," United Nations Press Release SC/6657 (March 24, 1999).

2. Ibid.

3. Ibid.

4. "Statement from the Federal Government' sMeeting," Federal Ministry ofInformation, Federal Republic of Yugoslavia (March 19, 1999).

5. Evan Luard, War in International Society (New Haven: Yale University Press, 1986), 93-100; Kalevi J. Holsti, Peace and War:

Armed Conflicts and International Order 1648-1989 (Cambridge: Cambridge University Press, 1991),26-34.

6. Tonny Brems Knudsen, "TheInternational Society Approach and the Post-Cold War Order: Conceptualizing Deep Change," paper presented at the 37th Annual Meeting of the International Studies Association, (April 16-20, 1996), 16; Reneo Lukic and Allen Lynch, Europe From the Balkans to the Urals: The Disintegration of Yugoslavia and the Soviet Union (New York: Oxford University Press, 1996), 272.

7. United Nations General Assembly Resolutions 43/131 (December 8,1988)

8. "Statement on Kosovo Issued by the Heads of State and Government particiand 461132 (December 19, 1991).
Council in Washington, DC, on 23rd and 24th April 1999," NATO Press Release S1(99)62.

9. JanE. Stromseth, "Iraq's Repression of its Civilian Population: Collective Responses and Continuing Challenges," in Enforcing Restraint: Collective Intervention in Internal Conflicts, edited by Lori Fisler foreign Relations, 1993),98; Lawrence Freedman and Efraim Karsh, The Gulf Conflict 1990-1991: Diplomacy and War in the New World Order (Princeton: Princeton University Press, 1993), 421-24.

10. Javier Solana, "NATO is Justified and Determined," Pittsburgh Post-Gazette (April 15, 1999).

11. KofiAnnan,

"SecretaryGeneralReflectson 'Intervention' in Thirty-Fifth Annual Ditchley Foundation Lecture," United Nations Press Release SG 1 SM/6613 (June 26, 1998).

12. "Chairman's Summary of the Meeting of the Euro-Atlantic Partnership Council at Summit Level, Washington D.C.," NATO Press Release EAPC-S(99)67 (April 25, 1999).

13. "Security Council Rejects Demand For Cessation of Use of Force Against Federal Republic of Yugoslavia," United 26,1999).

14. Anrei Kozyrev, "Russia: A Chance for Survival," Foreign Affairs 71, no. 2 (Spring 1992): 13. cl Damrosch (New York: Council on Nations Press Release SC/6659 (March

\section{PATHS TO EQUITY:}

\section{Cultural, Linguistic, and Racial Diversity in Canadian Early Childhood Education}

\section{By Judith K. Bernhard, Marie Louise Lefebvre, Gyda Chud, and Rika Lange}

Toronto: York Lanes PressISBN 1-55014-277-1; 112 pages, size 8.5x11; \$18.95

Paths to Equity is based on an extensive nationwide study of 77 childcare centres in Montreal, Toronto, and Vancouver on the cultural, linguistic, and racial diversity in Canadian Early Childhood Education (ECE). The report presents the results this study on how the ECE system is responding to the increasing diversity of contemporary Canadian society.

In this ground-breaking study, the authors have addressed teachers' views on diversity in the education programs; parents' difficulties in collaborating within the current education system; teachers' difficulties in understanding many "ethnic" parents; desire of many parents for better communication with staff, preferably in their own languages, and for more information about their individual children, and chances for effective input; and the evidence of some continuing problems with racism, irrespective of the good intentions of centre staff.

Paths to Equity will be of interest to ECE faculty, policymakers, centre supervisors and staff and others interested in the inclusion of diversity content in professional education programs. Available from:

Centre for Refugee Studies, Fax: (416) 736-5837. Email: refuge@yorku.ca

patingin the meeting of the North

Atlantic
Refuge, VoL 18, No.3 (August 1999) 